\title{
NEUROMONITORING DURING CARDIAC SURGERY IN A PATIENT WITH VENTRICULO-CAVAL SHUNT MIGRATION: CASE REPORT
}

\author{
Roberts Leibuss ${ }^{1,2}$, Inna Babuškina ${ }^{1,2, \#}$, Taisija Ženil̨enko ${ }^{1,2}$, Kristiāns Meidrops ${ }^{1,2}$, \\ Artis Kalninš3 ${ }^{3}$, Artjoms L̦išṇovs ${ }^{3}$, Artjoms Kalịnins ${ }^{2,3}$,' Žanna Pičkure ${ }^{2,3}$, \\ Eva Strīke ${ }^{1,2}$, and Pēteris Stradiñš ${ }^{1,2}$

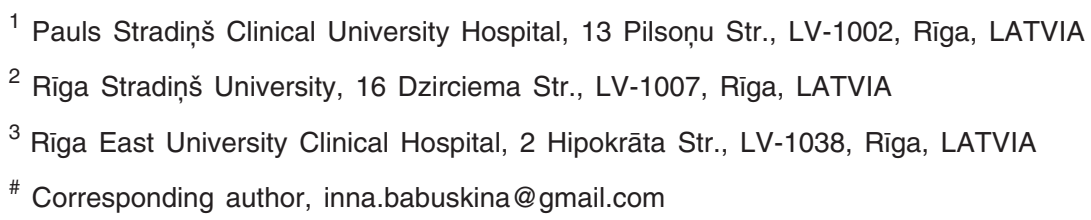

Contributed by Pēteris Stradiṇš

\begin{abstract}
Ventricular shunting is a well-recognised and commonly practiced method of reducing increased intracranial pressure in patients with neurologic pathology. There are possible complications related to shunt implantation, where the rarest is intracardiac migration of the distal shunt catheter. We present a case where the distal catheter migrated into the right ventricle, causing extrasystoles and was complicated with acute right ventricle failure during the endovascular shunt evacuation procedure.
\end{abstract}

Keywords: neuromonitoring, ventriculo-caval shunt, ventricular shunt migration.

\section{INTRODUCTION}

Ventricular shunting is a well-recognised and commonly practiced method of reducing increased intracranial pressure (ICP) in patients with a neurologic pathology, such as hydrocephaly caused by a tumour, trauma or infection. More than 40000 shunts are placed in the US every year. Nowadays, the method of choice is ventriculo-peritoneal shunting (VPS), because of easier performance and fewer complications (Wallace et al., 2014). Other choices are right atrium/v.cava superior (VCS) and pleural space. There are possible complications related to shunt implantation (shunt obstruction, infection, overdrainage, and intraventricular haemorrhage) where the rarest is intracardiac migration of the distal shunt catheter (Rizk et al., 2009). In 2010, there were only 13 registered cases. One of the latest cases was presented by Elens and Astarci (2017) about a man who had a shunt that migrated into the pulmonary trunk with an extension in a left segmental artery. We present a case where the distal catheter migrated into the right ventricle, causing extrasystoles and was complicated with acute right ventricle failure during the endovascular shunt evacuation procedure, which led to open-heart surgery with use of a cardiopul- monary bypass (CPB) and different types of non-invasive neuromonitoring for cerebral blood circulation evaluation and correction when needed. The aim of the demonstration was to show different methods of foreign body evacuation from the heart and the value of neuromonitoring during emergency cardiac surgery causing unstable haemodynamics, as well as to demonstrate the importance of multidisciplinary teamwork and co-operation between different medical centres for patient safety.

\section{CASE REPORT}

A 49-year old woman was admitted to Rīga East Clinical University Hospital complaining about an arrhythmic heartbeat, without any neurological disorders. It was known that in 1987 she underwent glandula pinealis tumour resection and VCS implantation (consisted of two parts - ventriculojugular and jugulo-caval). An electrocardiogram (ECG) showed ventricular extrasystoles, while Echo showed a foreign body in the heart right ventricle and pulmonal trunk. Head CT showed normal position of the shunt (right lateral ventricle), the ventriculo-jugular part of the shunt was still 

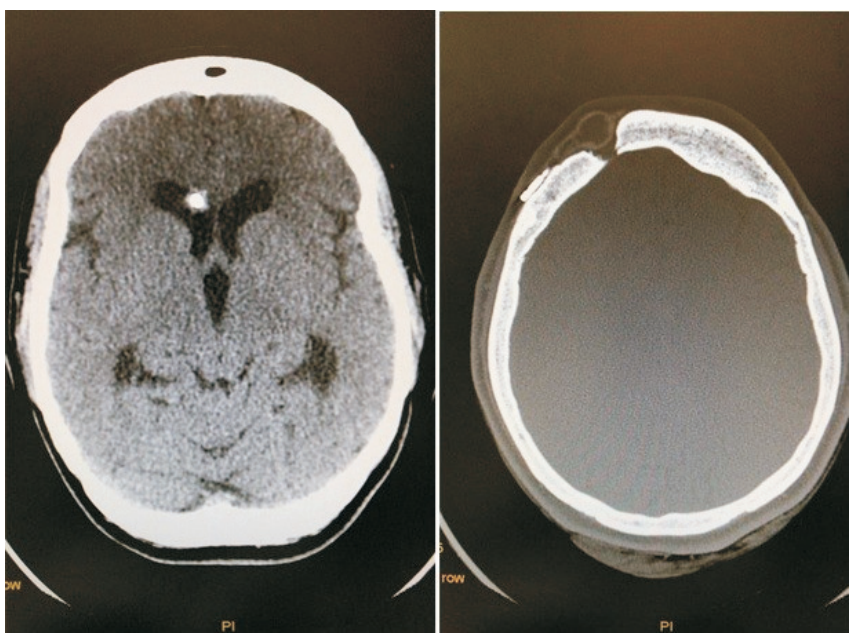

Fig. 1. Cranium computer tomography showed normal position of the shunt (right lateral ventricule), with non-acute brain pathology.

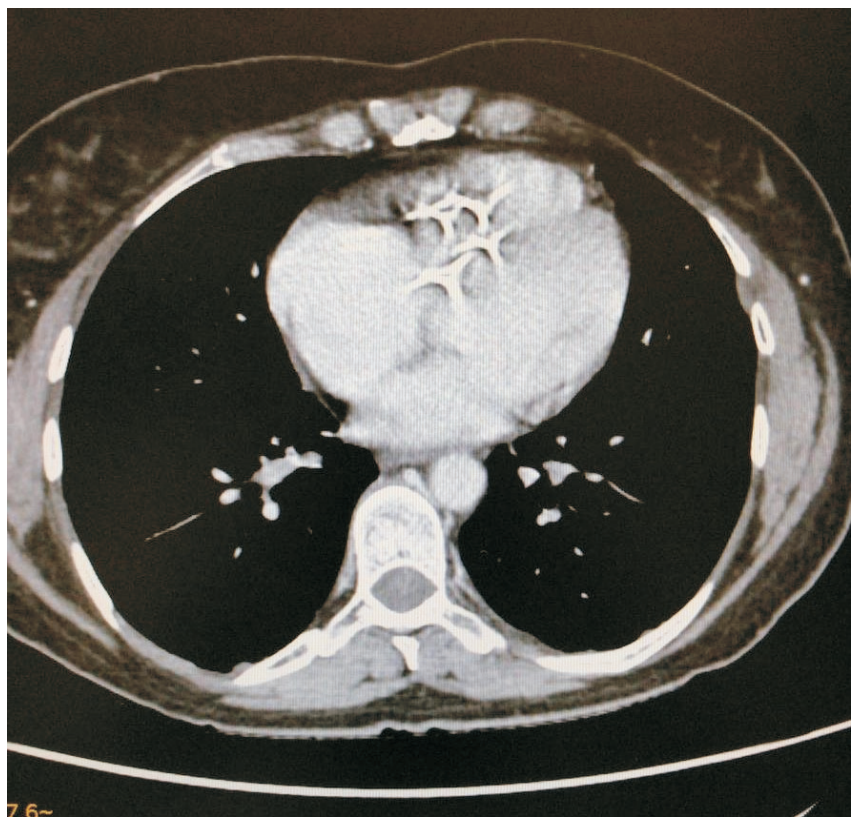

Fig. 2. Chest computer tomography showed double-loop-shape high density structure in the right ventricle (possible shunt)

working and no acute brain pathology was noticed (Fig. 1). Chest CT showed a Double-loop-shape high-density 9-cm structure (possible shunt) in the right ventricle, passing to the pulmonary trunk and left main pulmonary artery (Fig. 2). There was no shunt in v.cava superior and right atrium. On the next day there was an unsuccessful shunt endovascular evacuation (by tangling the snares) complicated by tricuspid valve perforation and incomplete obstruction of the pulmonary trunk. Therefore, the patient was

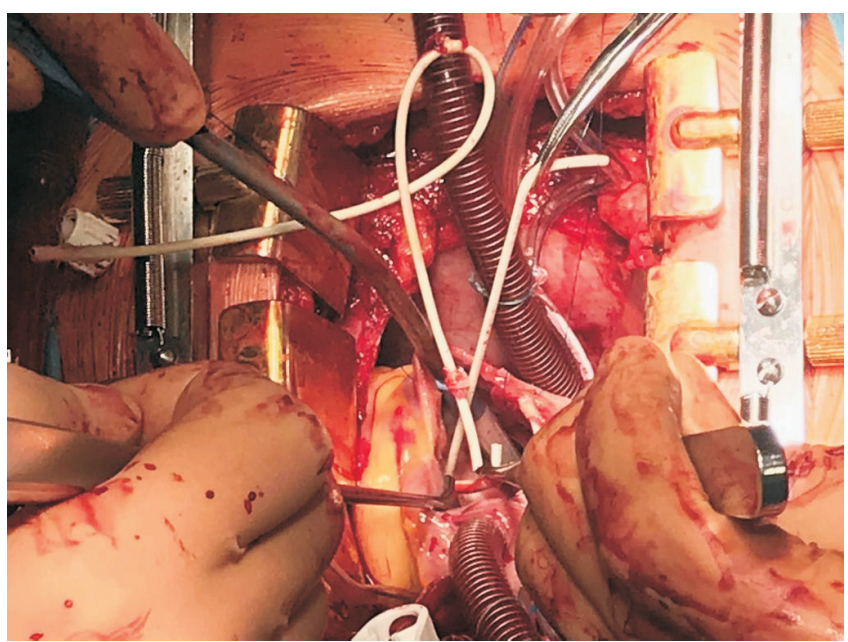

Fig. 3. Ventriculo-atrial shunt removal from the right ventricle and pulmonary trunk using traction.

transferred to Pauls Stradiņš Clinical University Hospital for emergency open cardiothoracic surgery (Table 1). After the median sternotomy, bicaval cannulation was established and a cardiopulmonary bypass (CPB) were initiated. A cross-clamp and antegrade crystalloid cardioplegia were used. We performed a right atriotomy and detected a loop of ventriculo-atrial shunt (VAS) fragment with a capture device that twisted between the trabecula in the right ventricle. The capture device was cut off and released, however the shunt was attached to the tricuspid valve by many adhesion bonds, which made it impossible to remove it using traction. The adhesion sites were cut, and the parts of the shunt were removed easily since they were not attached to other intracardiac structures (Figs. 3-4). The tricuspid valve was inspected for damage and left without repair. The right atriotomy was closed and the cross-clamp was released. Intraoperative transesophageal echocardiography (TEE) showed the 2nd degree of tricuspid insufficiency (Fig. 5). The rest of the capture device and sheath from the right femoral vein was removed. The surgery was performed under combined general anaesthesia, supported by CPB. Intraoperative neuromonitoring and neuroprotection were used to assess the function of the ventriculo-jugular part of the shunt and to reduce the risk of hydrocephalus, hypoperfusion and hyperperfusion of the brain (Tables 2-3). Because of the use of CPB and full blood heparinisation, we could not use invasive neuromonitoring. Therefore, we used:

- Transcranial Doppler ultrasound (TCD) to assess cranial blood flow velocity and the capability of circle of Willis compensation, as well as to monitor patency of cerebral arteries in order to avoid ischaemia or elevation of ICP

Table 1. Time framework of manipulations during patient's hospitalisation

\begin{tabular}{l|c|c|c|c|c|c|c|c|c|}
\hline \multicolumn{2}{l|}{18.02} & \multicolumn{2}{c|}{19.02} & & 20.02 & 21.02 & 28.02 \\
\hline Admitted to RECUH & ECG & EchoCG & Head CT & Chest CT & MIES & Transfer to PSCUH & OHS & ICU & Discharge from PSCUH \\
\hline
\end{tabular}

RECUH, Rīga East Clinical University Hospital; ECG, electrocardiogram; EchoCG, Echocardiography; CT, computer tomography; MIES, minimally invasive endoscopic surgery; PSUH, Pauls Stradiňš Clinical University Hospital; OHS, open heart surgery; ICU, Intensive Care Unit 


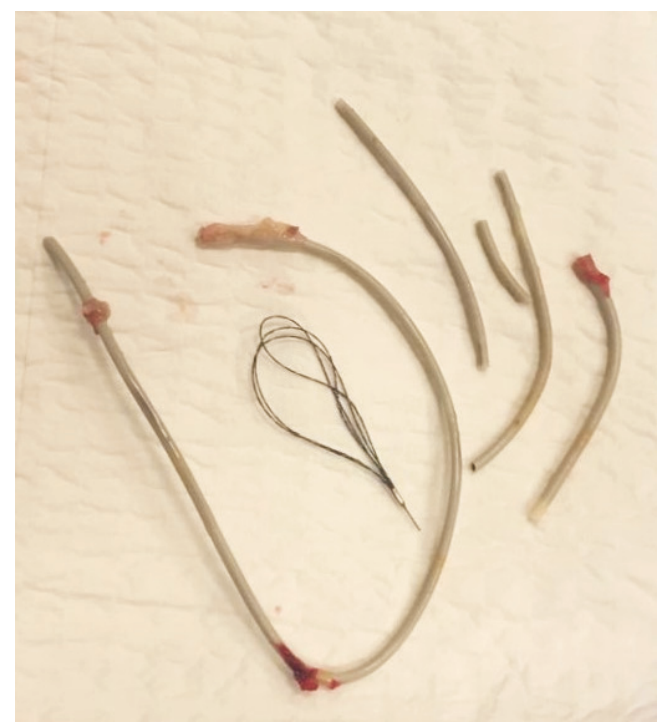

Fig. 4. Capture device with the fragments of v.cava superior.

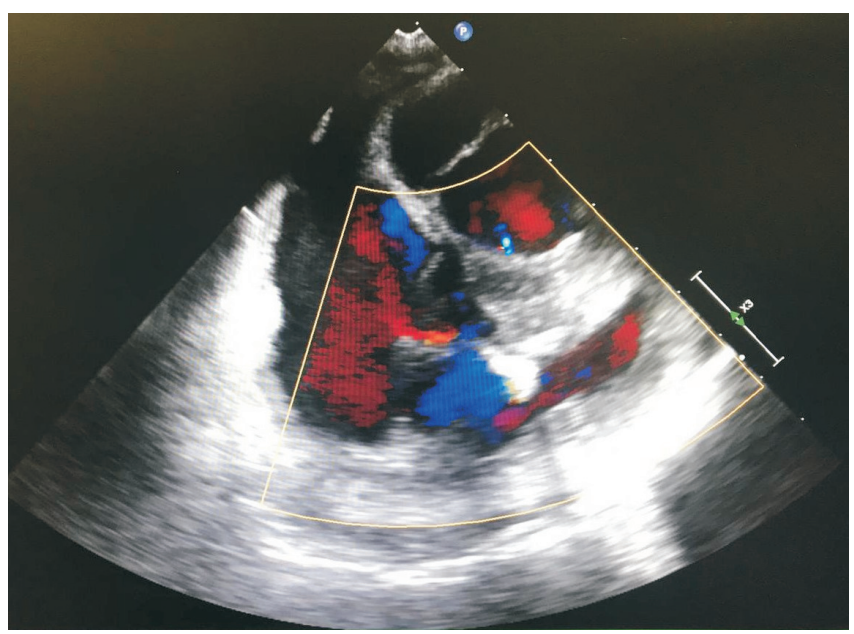

Fig. 5. Transesophageal echocardiography showed the 2nd degree of tricuspid insufficiency.

Table 2. Neuromonitoring rates during open-heart-surgery

\begin{tabular}{|c|c|c|c|c|}
\hline & & Before CPB & During CPB & After CPB \\
\hline TCD & $\begin{array}{l}\text { PSV } \\
\text { EDV } \\
\text { RI/PI } \\
\text { TAPV }\end{array}$ & $\begin{array}{l}93.2 / 87.3 \\
45.4 / 54.3 \\
0.51 \_0.78 / 0.38 \_0.50 \\
67.6 / 65.2\end{array}$ & $\begin{array}{l}65.8 / 65.3 \\
63.9 / 63.4 \\
0.03 / 0.03 \\
64.3 / 64.8\end{array}$ & $\begin{array}{l}96.7 / 110.0 \\
30.4 / 36.2 \\
0.69 \_1.26 / 0.67 \_1.21 \\
56.7 / 62.7\end{array}$ \\
\hline NIRS & & $61 / 54$ & $71 / 79$ & $69 / 75$ \\
\hline $\mathrm{SvjO}_{2}$ & & 77 & 73 & 75 \\
\hline EEG & & - & $2 *$ "burst suppression" & - \\
\hline
\end{tabular}

TDC, Transcranial Doppler Ultrasound; PSV, peak systolic velocity $(\mathrm{cm} / \mathrm{s})$; EDV, end-diastolic velocity $(\mathrm{cm} / \mathrm{s})$; RI, resistance index; PI, pulsatility index; TAPV, time-averaged peak-velocity; NIRS, Near Infrared Spectroscopy; $\mathrm{SvjO}_{2}$, jugular venous oxygen saturation; EEG, electroencephalogram

Table 3. Neuroprotection during open-heart-surgery

\begin{tabular}{lcccc}
\hline & Before CPB & During CPB & After CPB \\
\hline BT & 37.0 & 35.0 & 36.0 \\
BT\&NPT difference & $<1$ degree & $<1$ degree & $<1$ degree \\
Haematocrit & 42 & $24-27$ & 30 \\
pCO2 & 36 & 40 & 34 \\
Barbiturates & - & $0.25+0.25 \mathrm{~g}$ & - \\
Methylprednisolone & - & $500 \mathrm{mg}$ & - \\
Albumine 20\% & - & $100 \mathrm{ml}$ & - \\
Mannitol 25\% & - & $250 \mathrm{ml}$ & - \\
Haemofiltration & - & $1000 \mathrm{ml}$ & -
\end{tabular}

$\mathrm{CPB}$, cardiopulmonary bypass; BT, bladder temperature; NPT, nasopharyngeal temperature

Table 4. Patient's neuropsychological assessment

\begin{tabular}{c|c|c}
\hline & Before surgery & After surgery \\
\hline MMSE & 26 & 28 \\
MoCA & 26 & 27
\end{tabular}

MMSE, Mini-Mental State Examination; MoCA, Montreal Cognitive Assessment during surgery. In addition, by using TCD we could identify possible emboli from the heart (Montrief et al, 2019).

- Near Infrared Spectroscopy (NIRS) for continuous monitoring of regional cerebral oxygenation in order to observe development of regional cerebral ischaemia and correct it by pharmacological (by regulating the depth of anaesthesia) and non-pharmacological (local and generalised hypothermia) methods (Medical Advisory Secretariat, 2004).

- Jugular venous oxygen saturation $\left(\mathrm{SvjO}_{2}\right)$ to monitor the brain tissue demand for oxygen, i.e. brain metabolism, in order to recognise and prevent the cerebral ischaemia (Bhardwaj et al., 2014).

- Portative electroencephalography (EEG) and Bispectral index (BIS) to assess brain activity during anaesthesia; to detect "burst suppression"; and to evaluate the depth of anaesthesia (Nguyen et al., 2010).

During $\mathrm{CPB}$, a potassium-based solution in cardioplegia with addition of:

- $250 \mathrm{ml} \mathrm{15 \%} \mathrm{Mannitol} \mathrm{that} \mathrm{increased} \mathrm{blood} \mathrm{osmolarity,}$ thus reducing the amount of fluid in the extravascular 
space and minimising the positive fluid balance, as well as improving renal blood flow and acting as a nephroprotector;

- $200 \mathrm{ml} 20 \%$ Albumine that inhibited platelet count reduction, prevented their adhesion, decreased the use of coagulation factors and reduces fluid distribution;

- Barbiturates, that decreased cerebral metabolism and need for oxygen;

- Patient's red blood cells, re-perfused by Cell-Saver to constantly maintain a high level of Ht.

After surgery, the patient was transferred to ICU where she spent one day. The total hospitalisation time after surgery was eight days. A neuropsychological assessment was done and the patient was discharged from the hospital without any complications (Tables 1 and 4).

\section{DISCUSSION}

Nowadays, VAS's take place only when VPS's are contraindicated. VAS's are associated with many complications such as shunt occlusion, venous thrombosis, pulmonary embolisms, heart valve failures etc. (Vargas-Barron et al., 1991). Shunt migration to other parts of the heart is a less common complication, but our clinical case shows that this is still possible. Until now, the mechanism of shunt migration is not clear. Some researchers consider that orthograde blood flow, vein valves and negative intrathoracic pressure pull the catheter within the venous system toward to the heart (Rizk et al., 2009). Some authors believe that excessive neck movements, producing a windlass effect, may cause shunt migration (Elens and Astarci, 2017). Usually, patients with shunt dislocation have neurological disorders (nausea, decreased level of consciousness, seizures) with no cardiac complains (Wallace et al, 2014). In contrast, our patient did not have neurological symptoms, because of a two-part-shunt, one of which (ventriculo-jugular part) was still working normally. Nowadays, surgeons do not prefer to implant such a type of shunt; however, in this case, it helped to save the patient's life without any neurological consequences. The ECG, X-ray and Echo results may help in identifying cardiac complications of the VAS. Most commonly, but not necessarily, the ECG sign is RBBB. Our patient did not have such changes in the ECG; this confirms a statement that ECG changes are not specific for this pathology and need to be replaced with other types of examination. Echo can reveal enlargement of right heart parts and tricuspid stenosis or regurgitation, as well as location of the shunt distal part. Patients with VAS should undergo an Echo and pulmonary function test every 12 months, because of the risk of serious complications (Vargas-Barron et al., 1991; Wallace et al., 2014). There are different treatment strategies for VAS migration: removal of the catheter via retroauricular incision, endovascular routes using snares (method of choice), and open-heart surgery as a last option (Naiki et al., 2013). In our case, the treatment strategy was similar to the common recommendations in the literature, but unfortunately, the endovascular technique was unsuccessful. It is recommended to use advanced neuromonitoring and neuroprotective approaches during cardiac surgery with $\mathrm{CPB}$ for patients with high perioperative unstable haemodynamic and neurological risk. Without intraoperative neurological evaluation, we cannot recognise the potency of cerebral circulation, and cannot monitor how cerebral circulatory autoregulation responds to decreased cardiac output and cerebral perfusion (due to acute heart insufficiency and unstable haemodynamics). Thus, it can end with major neurological impairment or even death. By controlling the situation, we can immediately respond with pharmacological and non-pharmacological methods such as increasing the local or generalised hypothermia and providing deeper anaesthesia (to reduce the brain metabolism) etc. Unfortunately, because of full heparinisation and CPB, we could not use the invasive approach of neuromonitoring. However, nowadays, there are plenty of non-invasive methods that can help. TCD is a non-invasive and cheap method of assessing cerebral blood flow velocity, within the intracranial circulation through relatively thin bone windows (Montrief et al., 2019). It is mostly used in the diagnosis of some neurological pathologies, but sometimes for the intraoperative monitoring of patency of cerebral arteries to avoid the ischaemia and elevation of ICP (Razumovsky et al., 2009). The most frequent indications for TCD are Midline shift, vasospasm, acute ischemic stroke and raised intracranial pressure (Montrief et al., 2019). TCD ultrasound does not directly measure cerebral blood flow. However, if we assume that vessel diameter does not change significantly, the CBFV (cerebral blood flow velocity) is directly proportional to flow, and therefore changes in CBFV detects change in CBF and might show blood flow reduction/ischaemia in the brain region (Razumovsky et al., 2009). Some authors consider that TCD sensitivity is 86-96\% in first 24 hours after acute stroke (Babikian, 1993; Razumovsky et al., 2009; Montrief et al., 2019). In addition, some authors consider TCD as a tool for noninvasive measurement of ICP, showing good concordance between invasive and TCD-based ICP measurements. Increased ICP externally compresses cerebral vessels, which leads to constriction of the blood vessel and consequently to increased systolic velocity (Montrief et al., 2019). NIRS is an optimal imaging modality used to examine brain activity changes by measuring tissue blood flow changes (dynamic NIRS i.e. DCS-diffuse correlation spectroscopy) and tissue oxygenation (static NIRS) (Hosomi et al, 2019; Hou et al., 2019). It is an attractive and accessible approach to investigate brain activity changes with its high temporal resolution, robustness to electrical artefacts, and low cost (Kim et al., 2019). The device measures relative changes in oxygenated- (oxy-), deoxygenated- (deoxy-) and total $\mathrm{Hb}$ concentrations, and oxygen saturation using different wavelengths (Hosomi et al, 2019; Hou et al., 2019). However by measuring the blood flow, we can obtain information about the velocity and efficiency of oxygen that is carried in the blood and supplied to the tissue. Thus, the combination of these two parameters provides an estimate of the oxygen metabolic rate and, therefore, potential tissue pathology (Hou et $a l ., 2019)$. The first uses of NIRS and DCS were for assess- 
ment of autoregulation capability, therapeutic monitoring of ischaemic stroke and early detection of tumours. However, now it is widely used in intraoperative monitoring, for example, to check the anaesthetic effect on the brain or to detect ischaemia during the occlusion of artery in vascular surgery (carotid and femoral arterial surgeries) (Shang et al., 2011; Yu et al., 2011; Choi et al., 2016; Hou et al., 2019). $\mathrm{SvjO}_{2}$ - the saturation of venous blood that flows from the brain and sampled from the jugular bulb gives an estimate of cerebral oxygenation, cerebral blood flow and cerebral metabolic requirement, which might help to detect cerebral ischaemia (Joly and Mertes, 2006; Bhardwaj et al., 2015). In other words, the $\mathrm{SvjO}_{2}$ value gives information about the balance between cerebral oxygen supply and demand. It is used to guide physiologically based management of various clinical situations, including traumatic brain injury during neurosurgery and cardiopulmonary bypass (Nakajima et al., 1992; Bhardwaj et al., 2015). In a healthy brain flow-metabolism coupling is preserved and $\mathrm{SvjO}_{2}$ ranges between $55 \%$ and $75 \%$ (Gibbs et al., 1942). Values below 54\% imply that oxygen supply may be critically low for the metabolic demand and that the brain is at risk for ischaemic injury. Causes may be reduced supply of oxygen (Cerebral vasoconstriction, hypocapnia, vasospasm, hypotension, anaemia, and sepsis) or increased oxygen requirement (increased cerebral metabolism, fever, inadequate sedation, and pain). A value more than $75 \%$ is representative of cerebral hyperemia or decreased oxygen extraction, as in cerebral infarction. In that case, causes may be increased oxygen supply (cerebral vasodilation, hypercapnia, and hypertension) or reduced oxygen requirement (deep sedation, coma, hypothermia, cerebral infarction, and brain death) (Bhardwaj et al., 2015). However, the interpretation of $\mathrm{SvjO}_{2}$ values remains only as a part of a complex, and should be measured in addition to cerebral haemodynamic monitoring, ICP and TCD (Joly and Mertes, 2006). Bispectral index, which is a multiprocessor EEG parameter, identifies changes in electrophysiologic brain activity during general anaesthesia, thus predicts the level of hypnosis (Medical Advisory Secretariat, 2004). Use of BIS gives the opportunity to titrate hypnotics on cortical activity, consequently to keep an adequate anaesthesia level with baseline medication concentration, and therefore to carry out anaesthesia with minimal resources. Other benefits using the BIS are: the reduction of extubation time, better patient's orientation in time and place afterwards, less PONV and less time in the surgery room (Oliveira et al., 2017). Some authors consider that using BIS to determine the depth of anaesthesia leads to decreased incidence of POCD (Postoperative cognitive dysfunction) in the early post-operative period (An et al., 2011; Quan et al., 2019). In addition, there is a significant link between deep anaesthesia (as indicated by low BIS) and postoperative mortality in patients given a follow-up duration $\geq 90$ days, especially in patients who underwent cardiac surgery (Liu et al., 2019). In patients who are awake, the typical BIS score is 90 to 100 . Lower numbers indicate a higher hypnotic effect. A BIS value below 60 is associated with a low probability of response to commands (Medical Advisory Secretariat, 2004). We consider that the rational amount of neuromonitoring in cardiac bypass surgery is combination of NIRS, TDC and $\mathrm{SvjO}_{2}$, however, the minimal acceptable tool in case of limited resources is $\mathrm{SvjO}_{2}$. Based on practice, Latvian cardioanaesthesiologists usually use NIRS, TDC, and $\mathrm{SvjO}_{2}$. We do not give preference to any particular method and try to use them together, as we believe that only combined they can provide answers to complex questions related to maintaining adequate cerebral perfusion during cardiac surgery. In this case, we performed all methods of neuromonitoring in order to distinguish nerologic impaitment. Thanks to neuroprotective procedures and medications, our patient did not receive any neurological complications in the perioperative period.

\section{CONCLUSION}

A ventriculo-caval shunt is not the method of choice to reduce ICP, however, currently there are still patients that have it. Thus, we should be aware of VCS complications, including shunt migration into the heart. Only a multidisciplinary team should decide which method of treatment can be used in each case. The doctors should be aware of endovacular treatment complications, so it is better to perform the procedure in a hospital where the patient can be easily transported to the operating theatre. It is important to prepare emergency treatment logistics between hospitals for patient's safe transportation to a specialised medical centre.

All cardiac surgeries due to acute heart failure (no matter the cause) are considered as high-risk procedures. The medical team should always be aware of unstable haemodinamics during the perioperative period, which can cause a drop of the cerebral circulatory system, leading to brain ischaemia and fatal damage. To have an opportunity for immediate reaction on cerebral perfusion changes, we should always consider to use advanced neuromonitoring during the high-risk surgeries (not only CPB-surgeries). It would be more precise to use invasive neuromonitoring, which however it is not always feasible because of emergencies and requirement of anticoagulated blood. Nowadays there are plenty of non-invasive neuromonitoring devices. Practitioners can use each of them individually, or even better, in a combined way. As described above, each non-invasive neuromonitoring approach complements each other, so the medical team should choose a method according to their capabilities and accessibility of the devices. In conclusion, by using neiromonitoring, we have an opportunity to recognise even tiny changes in cerebral circulation and perfusion and to treat them intraoperatively, in order to minimise neurological complications in the perioperative period, and thereby to decrease the mortality rate and patient hospitalisation days.

\section{REFERENCES}

An, J., Fang, Q., Huang, C., Qian, X., Fan, T., Lin, Y., Guo, Q. (2011). Deeper total intravenous anesthesia reduced the incidence of early postoperative cognitive dysfunction after microvascular decompression for facial spasm. J. Neurosurg. Anesthesiol., 23 (1), 12-17. 
Babikian, V., Sloan, M. A., Tegeler, C. H., DeWitt, L. D., Fayad, P. B., Feldmann, E., Gomez, C. R. (1993). Transcranial Doppler Validation Pilot Study. J. Neuroimaging, 3 (4), 242-249.

Bhardwaj, A., Bhagat, H., Grover, V. K. (2015). Jugular venous oximetry. J. Neuroanaesthesiol. Crit. Care, 2 (3), 225-231.

Choi, D.-H., Shin, T. J., Kim, S., Bae, J., Cho, D., Ham, J., Kim, J. G. (2016). Monitoring of cerebral oxygenation and local field potential with a variation of isoflurane concentration in a rat model. Biomed. Opt. Expr., 7 (10), 4114.

Elens, M., Astarci, P. (2017). Ventriculo-caval shunt migration. Eur. J. Vasc. Endovasc. Surg., 54 (2), 263.

Hosomi, F., Yanagi, M., Kawakubo, Y., Tsujii, N., Ozaki, S., Shirakawa, O. (2019). Capturing spontaneous activity in the medial prefrontal cortex using near-infrared spectroscopy and its application to schizophrenia. Sci. Rep., 9, 5283.

Gibbs, E. L., Lennox, W. G., Nims, L. F., Gibbs, F. A. (1942). Arterial and cerebral venous blood: Arterial-venous differences in man. J. Biol. Chem., 144, 325-332.

Hou, L., Liu, Y., Qian, L., Zheng, Y., Gao, J., Cao, W., Shang, Y. (2019). Portable near-infrared technologies and devices for noninvasive assessment of tissue hemodynamics. J. Healthc. Eng., 2019, 1-11.

Joly, L.-M., Mertes, P.-M. (2006). Intérźt du monitorage de l'oxygénation cérébrale par $\mathrm{SvjO}_{2}$ ou $\mathrm{PtiO}_{2}$. Annales Franēaises d'Anesthésie et de Réanimation, 25 (7), 748-754.

Kim, E., Anguluan, E., Youn, S., Kim, J., Hwang, J. Y., Kim, J. G. (2019). Non-invasive measurement of hemodynamic change during $8 \mathrm{MHz}$ transcranial focused ultrasound stimulation using near-infrared spectroscopy. BMC Neurosci., 20 (1), 12.

Liu, Y.-H., Qiu, D.-J., Jia, L., Tan, J.-T., Kang, J.-M., Xie, T., Xu, H.-M. (2019). Depth of anesthesia measured by bispectral index and postoperative mortality: A meta-analysis of observational studies. J. Clin. Anesth., 56, 119-125.

Montrief T., Alerhand S., Jewell C., Scott J. (2019). Incorporation of Trancranial Dopler into the emergency department for the neurocritical care patient. Amer. J. Emerg. Med., 37, 1144-1152.

Naik, V., Phalak, M., Chandra, P. S. (2013).Total intracranial shunt migration. J. Neurosci. Rural Pract., 4 (1), 95-96.
Nguyen, H. S., Turner, M., Butty, S. D., Cohen-Gadol, A. A. (2010). Migration of a distal shunt catheter into the heart and pulmonary artery: Report of a case and review of the literature. Child's Nervous Syst., 26 (8), 1113-1116.

Oliveira, C. R., Bernardo, W. M., Nunes, V. M. (2017). Benefit of general anesthesia monitored by bispectral index compared with monitoring guided only by clinical parameters. Systematic review and meta-analysis. Brazilian J. Anesthesiol., 67 (1), 72-84.

Quan, C., Chen, J., Luo, Y., Zhou, L., He, X., Liao, Y., Wen, O. (2019). BIS-guided deep anesthesia decreases short-term postoperative cognitive dysfunction and peripheral inflammation in elderly patients undergoing abdominal surgery. Brain Behav., 9, e01238.

Razumovsky, A. V., Gillard, J. H., Bryan, R. N., Hanley, D. F., Oppenheimer, S. M. (2009). TCD, MRA, and MRI in acute cerebral ischemia. Acta Neurol. Scand., 99 (1), 65-76.

Rizk, E., Dias, M. S., Verbrugge, J., Boop, F. A. (2009). Intracardiac migration of a distal shunt catheter: An unusual complication of ventricular shunts. J. Neurosurg. Pediatr., 3 (6), 525-528.

Shang, Y., Cheng, R., Dong, L., Ryan, S. J., Saha, S. P., Yu, G. (2011). Cerebral monitoring during carotid endarterectomy using near-infrared diffuse optical spectroscopies and electroencephalogram. Phys. Med. Biol., 56 (10), 3015-3032.

Medical Advisory Secretariat (2004). Bispectral Index Monitor: An Evidence-Based Analysis. Ont. Health Technol. Assess Ser., 4 (9), 1-70.

Nakajima, T., Kuro, M., Hayashi, Y., Kitaguchi, K., Uchida, O., Takaki, O. (1992). Clinical evaluation of cerebral oxygen balance during cardiopulmonary bypass: On-line continuous monitoring of jugular venous oxyhemoglobin saturation. Anesth. Analg., 74 (5), 630-635.

Vargas-Barron, J., Buenfil-Medina, C., Sanchez-Ugarte, T., Keirns, C., Rocha-Maguey, J., Romero-Cardenas, A., Lupi-Herrera, E. (1991). Ventriculoatrial shunts for hydrocephalus and cardiac valvulopathy: An echocardiographic evaluation. Amer. Heart J., 121 (5), 1498-1501.

Wallace, A. N., McConathy, J., Menias, C. O., Bhalla, S., Wippold, F. J. (2014). Imaging evaluation of CSF shunts. Amer. J. Roentgenol., 202 (1), 38-53.

Yu, G., Shang, Y., Zhao, Y., Cheng, R., Dong, L., Saha, S. P. (2011). Intraoperative evaluation of revascularization effect on ischemic muscle hemodynamics using near-infrared diffuse optical spectroscopies. $J$. Biomed. Optics, 16 (2), 027004(1-11).

\section{INTRAOPERATĪVAIS NEIROMONITORINGS PACIENTEI AR VENTRIKULO-KAVĀLA ŠUNTA MIGRĀCIJU KARDIOTORAKĀLAS OPERĀCIJAS LAIKĀ: GADĪJUMA ZIN̦OJUMS}

Ventrikulāra šuntēšana ir atpazīstama un plaši pielietota metode, ko izmanto paaugstināta intrakraniālā spiediena mazināšanai pacientiem ar neiroloğiskām patolog̣ijām. Līdzīgi kā citām manipulācijām, arī ventrikulārai šuntēšanai iespējamas komplikācijas. Viena no visretākajām komplikācijām ir katetra distālā gala migrācija sirdī. Šajā klīniskajā gadījumā tiek aprakstīta ìpaši reta situācija — katetra distālā gala migrācija uz sirds labo kambari, kas rezultējās ar ekstrasistolēm un akūtu labā kambara mazspēju endovaskulāras šunta evakuācijas laikā. 